\title{
How cool is that! A new 'construction' and its theoretical challenges
}

\author{
Andreas Trotzke ${ }^{1,2}$
}

Received: 12 March 2019/Accepted: 10 January 2020/Published online: 30 November 2020

(C) The Author(s) 2020

\begin{abstract}
This paper deals with the controversial connection between sentence type and illocutionary force. I focus on wh-configurations of the form How cool is that! and demonstrate that this recent phenomenon presents some interesting challenges to approaches that are concerned with the illocutionary potential of sentence forms. In particular, the exclamation component of How cool is that! cannot be derived from features of exclamative syntax, but rather is a cumulative effect of exclamative intonation, the respective adjective, and the degree reading of how. However, the $\mathrm{V}$-to-C-movement property results in a special pragmatics that proper exclamatives (i.e., without V-to-C movement: How cool that is!) lack. I claim that How cool is that! asks for affirmation or objection on the part of the addressee, and that this addressee-oriented component is signaled by a dedicated class of modal particles in the German version(s) of How cool is that! To analyze these addressee-oriented exclamations $(A-E X C S)$, I adopt a syntactic approach to the connection between sentence types and their potential illocutionary uses and thus argue that this connection is by no means arbitrary and unrestricted. I show that both the special pragmatic function of How cool is that! and the corresponding distribution of modal particles in the German counterparts can be accounted for by referring to a compositional conception of sentence-type meanings, and I hence disagree with recent approaches that deal with How cool is that! and its counterparts in German as constructions (i.e., arbitrary form-function mappings) only.
\end{abstract}

Keywords Construction · Exclamation - Exclamative · Interrogative · Modal particle $\cdot w h$-question

Andreas Trotzke

andreas.trotzke@uni-konstanz.de

1 Department of Linguistics, University of Konstanz, Konstanz, Germany

2 Center for Theoretical Linguistics, Autonomous University of Barcelona, Barcelona, Spain 


\section{Introduction}

In linguistic typology, a distinction is often made between so-called 'major' and 'minor' sentence types. There is an overall consensus that declaratives (1a), interrogatives (1b), and imperatives (1c) belong to the class of major sentence types, while exclamatives, for instance, probably instantiate a minor type (2); see, for example, König and Siemund (2007, 2013).

(1) a. That building is tall.

b. Has that building been extended?

c. Go to the top of that building!

(2) What a tall building that is!

In this paper, I will focus on a subclass of non-standard uses of interrogatives, namely on special uses of how-interrogatives. I will present the new observation that utterances like English How cool is that! have in fact a hybrid status: they function as both speaker-oriented exclamations (like [2]) and addressee-oriented questions (like [1b]). Drawing on cross-Germanic evidence from English and German, I will specify the pragmatic contribution of How cool is that! as addressee-oriented exclamation $(A-E X C)$. The evidence discussed in this paper will show that this unique pragmatic function is indicated by a combination of both non-syntactic means and compositional syntax. Since A-EXCs are characterized by a complex interplay of intonational, syntactic, and lexical factors, a construction-oriented analysis that can assemble these diverse aspects under one 'construction' seems to be a natural account at first sight.

In a seminal paper on German sentence types, Reis (1999) has distinguished between 'derivational approaches' and 'correspondence approaches'. Correspondence approaches, in contrast to derivational views, leave more room for nonsyntactic factors (e.g., intonation, pragmatics, lexical choice) to determine the illocutionary force of a syntactic utterance. These accounts assign several aspects of different linguistic levels to a particular sentence type and thereby correspond to the general construction-based view on language, according to which "generalizations about linguistic structure are formulated in terms of $[\ldots]$ conventionalized clusters of features (syntactic, prosodic, pragmatic, semantic, textual, etc.) that recur as further indivisible associations between form and meaning" (Fried 2015, 974).

In this paper, I will challenge recent construction-oriented approaches to utterances of the form How cool is that! In particular, I agree with such approaches that the exclamatory reading (i.e., the speaker is surprised/astonished that $x$ is cool to an extreme degree) is yielded by an (idiosyncratic) set of non-syntactic factors. However, I will argue that morphosyntactic operations such as V-to-C movement still encode an illocutionary meaning component that sets these forms apart from their corresponding wh-exclamatives. Accordingly, the constructionist view on How cool is that! must be complemented by a compositional approach to sentence-type meaning to fully account for the special pragmatics of How cool is that! and its 
counterparts in other languages like German. Note also that neither cool nor the demonstrative that are obligatory components of this configuration-another argument against its idiomatic status. As I will show below, one can use any lexical items. However, in what follows I will mostly use How cool is that! for illustration purposes.

The paper is structured as follows. In Sect. 2, I will first discuss and then dismiss the idea that utterances of the form How cool is that! could be analyzed as a subtype of $w h$ exclamatives. In particular, after having looked at both the left periphery (Sect. 2.1) and the wh-constituent (Sect. 2.2) of wh-exclamatives and How cool is that!, I will conclude that there is no defining feature of $w h$-exclamatives that could explain the exclamation reading of configurations like How cool is that! Section 3 presents the main claim of the paper, namely that utterances like How cool is that! are addresseeoriented exclamations (A-EXCs) and thus feature a special pragmatics, which can be derived from both their non-syntactic features (like intonation, nature of the adjective; Sect. 3.1) and their syntactic makeup (Sect. 3.3). Crucial evidence supporting such an approach that combines insights from 'derivational' and 'correspondence' approaches will be taken from the German language (Sect. 3.2), where modal particles play an important role in performing the speech act associated with the syntactic form of A-EXCs. Section 4 summarizes and concludes the paper.

\section{How cool is that! Rethinking the formal characteristics of exclamations}

Intuitively, if speakers utter How cool is that!, then they express that something has exceeded a certain degree of coolness that they had expected. In other words, these configurations express speaker surprise due to a violation of the speaker's expectation(s). At the level of illocutionary force, How cool is that! can thus be considered an exclamation, that is, an expressive speech act that conveys that a particular state-of-affairs has violated the speaker's expectations. As is well known from the literature on exclamations, they can be conveyed by different syntactic forms. Consider the following English examples, which are taken from Rett (2011, 412):

(3) a. (Wow,) John bakes delicious desserts!

b. (My,) What delicious desserts John bakes!

c. (Boy,) Does John bake delicious desserts!

d. (My,) The delicious desserts John bakes!

Looking at the data in (3), one could claim that exclamation is a speech act that does not correspond to a particular sentence type but rather to specific uses of several sentence types. Given the idea of derivational approaches that sentence types should be categorized based on their morphosyntactic features (see Sect. 1), there is thus no such thing as a dedicated sentence type for exclamations; potentially, any sentence type can receive an exclamatory interpretation, but this is due to non-syntactic 
features such as intonation that are (according to most derivational approaches) not relevant for defining sentence types.

On the other hand, there are influential accounts that postulate the category of an exclamative sentence type. For instance, we know that exclamatives can have a dedicated syntactic signature, such as what $a$ in What a delicious dessert John bakes! These elements can thus count as markers of exclamatives and their distribution can easily be accounted for when we postulate the category of exclamatives (see, e.g., Grimshaw 1979).

Our key example now raises interesting issues regarding these questions because although clearly functioning as an exclamation, it has the syntactic form of a whinterrogative and thus adds another option to the inventory given in (3). In Sect. 3, I will elaborate on the claim that this additional option can actually be characterized as an utterance type sui generis, namely as 'addressee-oriented exclamations' (AEXCs). To prevent any confusion right from the start and to improve the readability of the following sections, I will use the term A-EXCs already at this point of the paper to refer to configurations of the form How cool is that ${ }^{1}$

With this terminological choice in mind, let us now first turn to a discussion of the theoretical possibility of postulating structural differences in the left periphery of the clause that nevertheless might distinguish A-EXCs from their informationseeking wh-counterparts (Sect. 2.1). I will argue that there is no need to postulate extra functional structure for $w h$-exclamatives in the first place, and, based on this claim, I will thus conclude that left-peripheral syntax cannot help us to distinguish A-EXCs from regular wh-interrogatives. In Sect. 2.2, I will then turn to the internal structure of the $w h$-constituent and argue that the nature of both the $w h$-element and the adjective in A-EXCs cannot help us distinguishing between exclamations and other speech acts either. Section 2.3 summarizes the observations and concludes by briefly mentioning the main characteristics that can be observed in the domain of intonation.

\footnotetext{
${ }^{1}$ In what follows, I will use the term A-EXCs instead of the notion of 'pseudo-questions', which has previously been used in the literature (see Nye 2009). The reason for my terminological choice is that in contrast to the $[w h+A d j]$-cases discussed in the present paper, the following examples (i) and (ii) usually characterized as 'pseudo-questions'-do not express surprise about the degree to which a predicate expressed by an adjective holds and, in accordance with what I will claim for A-EXCs, thus do not ask to affirm the high degree to which such a predicate holds:

(i) Wer hat denn DEN Mist verzapft?!

who has PART this crap produced

'Who has produced this crap (implied answer: an idiot!)?!'

(ii) Wo ist denn DER hingefahren?!

where is PART this.one traveled.to

'Where has he traveled to (implied answer: a stupid place!)?!'

Rather, the two cases above convey surprise (or often also disapproval; see Munaro and Obenauer 1999) about a 'polar' situation: the speaker is surprised or annoyed about the fact that something either happened or did not happen (i.e., someone has messed things up or not; someone has traveled to a stupid place or not). As indicated by the paraphrases, in most of these cases the particle denn is used as a means to mark the rhetorical character of these questions (on this use, see recent work by Braun et al. 2018). That is, there is no affirmation-orientation as we find in the [wh+Adj]-cases discussed in the following sections. Obviously, the degree component of A-EXCs lends itself better to the affirmation component: it may be clear that something is 'cool', but the speaker might still want to know from the addressee if she shares his judgement that it is 'cool' to a very high degree.
} 


\subsection{How cool is that! and the left periphery of exclamations}

Looking at the English inventory of exclamation speech acts in (3) above, let us first assume, for the sake of argument, that at least forms like (3b) can be categorized as a separate sentence type because they do not work as regular $w h$-questions due to their V-in situ configuration. ${ }^{2}$ This is in accordance with most of the literature on English exclamatives (see Siemund 2015).

In particular, one could thus say that $w h$-exclamatives have a dedicated syntactic structure in English and can clearly be distinguished from $w h$-interrogatives (examples and judgments from Repp 2013, 66):

(4) a. [CP How long [TP this train journey could take]]!

b. [CP How long [C, could [TP this train journey eould take]]]?

c. *[CP How long [те this train journey could take]]?

d. *[CP How long [C , could [TP this train journey euld take]]]!

Accordingly, as far as the English language is concerned, our key example How cool is that! clearly features interrogative rather than exclamative word order. In terms of word order, it thus cannot count as an exclamative and can be used for both conveying a request for information (5b) and performing the speech act of an exclamation (5a); '\#' indicates pragmatic deviance in a dialogue:

(5) a. A: How cool is that!

[intended: exclamation] B: \# I don't know.

b. A: How cool is that (e.g., on a scale from 1 to 10)? [intended: question] B: To my mind, it's very cool (I'd rate it a 9).

Both (5a) and (5b) have the syntactic form of an interrogative, but only (5b) is interpreted as a question speech act. Example (5a), by contrast, is interpreted as an exclamation. That is, the utterance expresses that the degree of coolness is not in accordance with the speaker's expectations, and the speaker conveys that the propositional content (that a salient entity in the ongoing discourse is very cool) is true. This propositional part of the utterance is the reason why Speaker B's response is odd because in the response given in (5a), Speaker B addresses an issue that is already backgrounded in the ongoing discourse. For many, this 'backgrounding' is a signature property of exclamatives and can technically be characterized as a factivity presupposition (see below).

In sum, there is a clear difference in meaning between the two readings paraphrased in (5). However, there is no difference in their overt syntactic structure (i.e., word order). One theoretical possibility to nevertheless distinguish between the two readings (question vs. exclamation) on syntactic grounds is thus to refer to

\footnotetext{
${ }^{2}$ Note that other $w h$-initial configurations lacking V-to-C movement in English do not necessarily receive an exclamatory interpretation (e.g., Why bother? or How come?; see also recent work by Finkbeiner 2018 on German wh-verb-final newspaper headlines). In what follows, I will abstract away from these uses and occurrences of $w h$-structures and instead focus on the more prototypical cases of $w h$ questions and $w h$-exclamatives discussed in the literature.
} 
'covert' syntactic structure that has been claimed for the left periphery of exclamatives. One prominent approach in this regard is the theory by Zanuttini and Portner (2003), who refer to the backgrounding of descriptive content already mentioned above in their syntactic proposal.

More specifically, Zanuttini and Portner (2003), among others, have argued that exclamatives have a factive operator that interrogatives like (5b) lack. In their work, they focus on Paduan, which is spoken in the Italian city of Padua. They argue that this Romance variety provides direct evidence that exclamatives contain an extra $\mathrm{CP}$ layer of structure. Without going into too much detail here, let me briefly illustrate their analysis for an wh-exclamative like (6a); see Zanuttini and Portner (2003, 64):
a. Che alto che 1 ze!
what tall that SUBJECT.CLITIC is
'How tall he is!'
b. [CP che alto [[C $\varnothing]\left[\mathrm{CP}\right.$ FACT [ ${ }_{\mathrm{C}}$ che $\left.\left.\left.] \mathrm{IP}\right]\right]\right]$

The main point of the data and the analysis in (6b) is that two CP specifier positions are needed in order to provide a phrase-structural position for both the factive operator (also needed for embedded contexts introduced by che 'that') and the whphrase che alto ('what tall'). Zanuttini and Portner (2003) then argue, based on evidence showing that exclamatives always carry a factivity presupposition, that their analysis should be postulated for other languages too. Since exclamatives, according to their claim, are the only unembedded configurations that feature such a factivity presupposition, clause typing is taken care of by the factive operator, and there is no need to postulate additional projections like ForceP, let alone more specific ones like 'ExclamativeForceP' or the like. For such a Split-Force approach to exclamatives and further configurations that convey surprise on the part of the speaker, see, for example, Munaro and Obenauer (1999) and Obenauer (2006).

While approaches differ in their claims as to how much functional structure is needed to account for the syntax of exclamatives, many accounts in the spirit of Zanuttini and Portner (2003) share the central assumption that for languages like English, we have to postulate covert syntactic structure to syntactically distinguish between interrogatives and exclamatives.

In what follows, I would like to adopt a different approach and briefly illustrate the basic idea. Let us look at the exclamative counterpart of our key example How cool is that! in (7):

(7) How cool that is!

My claim is that even the overt syntactic structure (lacking V-to-C movement) is not a syntactic feature that can be used to distinguish exclamatives from other sentence types. Note that the word order of the $w h$-exclamative in (7), despite the presence of a $w h$-phrase, is in fact the syntax of a declarative, featuring no subject inversion (see Ginzburg and Sag 2000, 224 on this parallel): 
(7') [ [CP how cool [C $\varnothing]\left[{ }_{\mathrm{IP}}\right.$ that $[\mathrm{I}$ is $\left.\left.] \ldots\right]\right]$

Accordingly, only looking at the overt structure (word order), we see that exclamatives feature the syntax of declarative assertions. The only remaining structural difference in this domain is thus based on covert structure, namely the presence of the factive operator in a Split-CP approach like the one exemplified in (6b) above. But what if the evidence for such a factive operator is weakened?

It would take me too far afield to discuss all the semantic and pragmatic details that can be found in the literature on exclamatives to support the idea that exclamatives do not feature assertive force, but rather convey their descriptive content via factivity presuppositions. However, two facts are always mentioned, and they are mentioned as early as Grimshaw (1979) to support this idea: (i) exclamatives cannot be used as answers to information-seeking questions and (ii) the descriptive content of exclamatives cannot be denied. Let me briefly comment on these two points and start with (ii).

Fact (ii) has always been based on introspective judgments like the ones given in (8) and (9); see Rett (2011, 414):

(8) A: (Wow, John bakes delicious desserts!

B: No (he doesn't), these are store-bought. John's actually a terrible cook.

(9) A: (My,) What delicious desserts John bakes!

B: ? No (he doesn't), these are store-bought. John's actually a terrible cook.

In the literature, it has been claimed that the descriptive content of exclamatives (9), in contrast to declarative assertions (8), cannot be denied. However, this is not supported by recent experimental work on Spanish (Villalba 2017) and German exclamatives (Trotzke 2019), showing that the descriptive content of wh-exclamatives is indeed 'at issue' and can thus be denied. I refer the reader to these papers to see that judgments like the one given in (9B) do not stand up to empirical investigations that actually test and measure the acceptability of those patterns.

Fact (i) concerns Grimshaw's (1979) claim that exclamatives cannot be used as answers to questions. The patterns we see in (10), the argument goes, suggest that while declarative assertions can serve as answers to information-seeking questions (10B), exclamatives are infelicitous, even if they express exactly the same descriptive content as the declarative counterparts (10B'). One thus concludes that this is so because the descriptive content of exclamatives is a factivity presupposition, hence not asserted; and that the pattern in (10) can be identified with the more general observation that a question cannot be answered by a sentence that presupposes the answer (11); I give below Grimshaw's (1979, 321) data and judgments:

(10) A: How tall is John?

B: John is very tall.

B': \# How tall John is!
(11) A: Did John leave?

B: \# It's odd that he did.

B' \# I'd forgotten that he did.

Again, my response to the above argument is that it is not valid. To understand what is going on in (10), I would like to suggest that (12B) below is a felicitous discourse move because it matches the constituent question in (12A). (12B'), on the other 
hand, causes a mismatch at the level of information structure. To see this, look at the following examples:

(12) A: How fast was Eliud Kipchoge*? *current marathon world record holder B: Eliud Kipchoge was $[\text { very }]_{F}$ fast.

B':\# [How fast Eliud Kipchoge was! $]_{\mathrm{F}}$

While (12B) is thus a perfect answer to a narrow-focus question (12A), (12B') is odd, as already pointed out in the literature cited above. However, when the informationstructural context is changed by using the two different utterance forms as responses to a broad-focus question, we see a clear improvement of the exclamative (13B'):

(13) A: Tell me, how did Eliud Kipchoge do in the race?

B: My god! [He was very fast! $]_{F}$

B': My god! [How fast he was! $]_{F}$

I claim that $(13 \mathrm{~B})$ is also fine in such a context because it no longer expresses narrow focus as in (12B), but instead (due to different intonation) it can also be interpreted as an all-focus declarative.

Given that exclamatives can be used as responses to information-seeking questions and thus feature assertive force, I hypothesize that a covert factive operator is too strong a claim and that exclamatives should better be analyzed as configurations featuring (i) declarative word order (lacking subject inversion) and (ii) conveying an all-focus interpretation. According to this perspective, exclamatives fall into one category with other declarative configurations that express surprise on the part of the speaker. In the recent syntactic literature, these configurations have been analyzed as 'mirative focus' (Cruschina 2012, 2019; Authier and Haegeman 2019) or cases of 'emphasis for intensity' (Trotzke 2017a; Beltrama and Trotzke 2019), and some recent experimental work shows that their interpretation can indeed be distinguished from other information-structural readings (Trotzke 2017b; Destruel et al. 2019).

In terms of the syntactic derivation, this would mean that [wh+Adj] in $w h$ exclamatives targets the left periphery to express surprise on the part of the speaker just like other phrases can be moved there to instantiate mirative fronting in declaratives (see literature cited above; e.g., Trotzke 2017b; Cruschina 2019). Let us adopt the syntactic implementation from Trotzke (2017a) and assume that the respective operator $\mathrm{Emp}_{\text {[intensity] }}$ is hosted in a functional projection below the question/assertion operators that are, according to cartography (e.g., Rizzi 2014), located in the domain of ForceP. Emp [intensity] $_{\text {takes scope over the propositional }}$ core of the clause (FinP) (all-sentence focus, see above) ${ }^{3}$ :

\footnotetext{
${ }^{3}$ To be more precise, Trotzke (2017a) argues at length that 'emphasis for intensity' (e.g., mirative focus and other scalar forms of emphasis) is in complementary distribution with 'emphasis for contrast', which accounts for information-structural readings like contrastive focus and corrective focus. According to my approach, the projection EmpP can therefore host either constituents that are intensified $\left(\mathrm{EmpP}_{[\text {intensity] }}\right)$ or contrastively interpreted without referring to a scalar meaning component $\left(\mathrm{EmpP}_{\text {[contrast] }}\right)$. Since the latter information-structural interpretations are not relevant to our discussion in this section of the paper, I only use the simplified version in (14).
} 
(14)

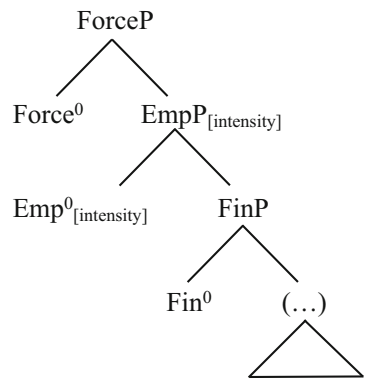

Crucially, data first mentioned by Bianchi and Cruschina (2016) suggest that the projection encoding the surprise of the speaker (here: $\mathrm{Emp}_{[\text {intensity] }}$ ) must indeed be located below Force because otherwise German data like (15) cannot be accounted for:

a. Du fährst morgen ans Meer?
you go tomorrow to.the seaside
'Are you going to the seaside tomorrow?'

b. Ans MEER fährst du morgen?

to.the seaside go you tomorrow

The emphatic effect of fronting in the polar question (15b) is interpreted with reference to the focus alternatives of the proposition $p$, and not with respect to its complement $\neg p$. Given that the polar set is generated by a Polar Question operator which takes the proposition $p$ as input, it makes sense to postulate that the Emp operator is below the Question operator because Emp must be located at a compositional level where the complement proposition $\neg p$ is not yet available.

The account by Trotzke (2017a) and Bianchi and Cruschina (2016) thus diverges from other more recent accounts that analyze the exclamation component as a modifier of illocutionary forces (e.g., Taniguchi 2017, 141-151). Although the approach presented here shares the basic assumption with Taniguchi (2017) that exclamatives do not have a force of their own, it conceptualizes the exclamation component along the lines of so-called mirative focus and thus locates the emphasis operator in the information-structural layer of the clause (see also fn. 3). According to this approach, exclamatives are nothing special and just another type of emphatic assertion, similar to declaratives with exclamative intonation, with lexical elements to mark unlikelihood like English even, or instantiations of mirative focus fronting.

Let us take stock. This section has provided some evidence for showing that there are good reasons to question the postulation of covert syntactic structure to distinguish between questions (16) on the one hand and exclamations on the other hand (17). In particular, both recent empirical work and recent theoretical proposals provide alternative ways to think about $w h$-exclamatives (17b), namely that they might fall into one class with other configurations displaying the same overt word order (declaratives lacking subject inversion). 
(16) How cool is that? [question]

(17) a. How cool is that! [exclamation]

b. How cool that is! [exclamation]

Accordingly, the burden of proof is on those who propose that there is covert structure that would allow putting (17a) and (17b), which feature different overt structure (word order), into one syntactic class. In what follows, I will thus assume that the exclamation component of (17a) cannot be explained by a dedicated leftperipheral syntax. But what about the 'interrogative' component? In other words, the more interesting question maybe is how the inversion syntax (17a) contributes to the exclamation reading of A-EXC configurations like How cool is that! But before turning to this question in more detail, let us first discuss a further aspect of A-EXCs that might distinguish this utterance from other sentence types: the nature of the $w h$ constituent.

\subsection{How cool is that! and the nature of the wh-constituent}

After having looked at (and dismissing) the theoretical possibility of deriving the exclamation reading of A-EXCs from covert structure that is shared with whexclamatives, let us now turn to a second domain where (5a) and (5b), repeated here for convenience, could differ in terms of structure: the internal structure of the $w h$ phrase.

(18) a. A: How cool is that!

[intended: exclamation]

B: \# I don't know.

b. A: How cool is that (e.g., on a scale from 1 to 10)? [intended: question]

B: To my mind, it's very cool (I'd rate it a 9).

An interrogative like (18b) presupposes that something is cool to a certain extent. The corresponding exclamation (18a) carries the same presupposition. However, (18a) expresses that the value of the open variable is located at an upper point of a given scale, whereas the interrogative expresses that the variable is to be filled by the addressee. Despite an abstract functional similarity, we thus see that the semantic role of the lexical item how within exclamative clauses is different from that within $w h$-interrogatives; in exclamatives, it corresponds to 'so', the typical degree element.

This is a well-known property of exclamations: they can feature so-called degree uses of certain wh-pronouns. To illustrate, let us adopt an approach by Krifka (2011) to question speech acts and assume that while the degree of the respective property is understood to be extraordinary in exclamatives, it is simply unspecified in interrogatives. That is, similar to regular questions, A-EXCs like How cool is that! denote a set of alternatives (however specified, e.g., by a function or by a proposition set). But in addition, these alternatives, according to Krifka (2011), are ordered along a d(egree) scale. In a proposition-set analysis, this order can be expressed as follows (see Krifka 2011, 1775): 


$$
\left.\left\{\left\langle\lambda \lambda_{i}\left[\operatorname{COOL}_{i}\left(\text { THAT }^{\prime} x^{\prime}\right)(d)\right], \lambda i\left[\operatorname{COOL}_{i}\left(\text { THAT }^{\prime} x^{\prime}\right)\left(d^{\prime}\right)\right]\right\rangle \mid d<d^{\prime}\right)\right\}
$$

Utterances of the form How cool is that! are thus (just like exclamatives) formed over a variable that ranges over degrees, like 'coolness' in our example.

Sometimes the degree use of wh-pronouns formalized in (19) has even been grammaticalized. For instance, what in interrogatives functions as the head of a nominal phrase (What did you read?), or as a determiner (What book did you read?). In exclamatives, however, what functions as a predeterminer (20a) and, in this use, cannot occur in interrogatives (20b); see Elliott $(1974,235)^{4}$ :

(20) a. What a fast car he is driving!

b. * What a fast car does John drive?

Such a distinction in terms of phrase structure also holds for other languages. It has been proposed that the degree reading of what, but also of how, has head status in exclamatives. Brandner (2010) has argued along these lines. That is, in German cases that are ambiguous between an interrogative and an exclamation interpretation (21a), she claims that wie ('how') is a head-element in the exclamation interpretation and thus behaves like was ('what') in (21b); examples from Brandner $(2010,108)$ :

(21) a. Wie bist du groß geworden!/?
how are you big become
b. Was bist du groß geworden!/*?
what are you big become
'How tall you became!'

She provides a body of empirical evidence for the claim that both was and wie correspond to the degree element 'so', and that these elements adjoin in a clitic-like fashion to the finite verb in the $\mathrm{C}$ position"

(22) [CP [C, was/wie bist [IP du groß geworden]]] what/how are you big become

'How tall you became!'

But can the non-degree and the degree use of $w h$-pronouns (and the corresponding phrase-structural differences claimed in the literature) now help us in distinguishing between the question and the A-EXC reading of How cool is that? Only looking at the phrase-structural status, I claim that these differences cannot account for the ambiguity of the string How cool is that. In particular, it is clear that how +adjective sequences (because of the modifying function of how) clearly have phrasal status and thus correspond to the general phrasal makeup we see in a regular wh-question,

\footnotetext{
${ }^{4}$ Note that the distinction between predeterminer and determiner is covert in plurals (e.g., what disasters) or mass singulars (e.g., what energy).

5 For instance, Brandner (2010) discusses the fact that these degree wh-elements in exclamatives cannot be stressed and cannot be coordinated, showing that they are indeed clitic-like elements.
} 
namely that the $w h$-element, together with the adjective, occupies the Spec-CP-and not the C-position in such questions:

(23) [CP [AP how cool] [C, is [IP that]]]

At this level of consideration, we can thus conclude that wh-questions (18b) and A-EXCs like How cool is that (18a) do not display differences at the structural level: both exhibit T-to-C movement and Spec-CP is filled by a phrasal constituent containing a wh-element.

Of course, there are structural differences when looking inside the wh-constituent -and these differences have been analyzed extensively in the literature (some of which has been cited above). As already mentioned above, the wh-pronoun in the exclamation reading of How cool is that! has a degree reading that corresponds to the degree marker $s o$ and can be formalized as follows (' $\gg \theta^{\prime}=$ 'going beyond a threshold'); see, among others, Kennedy and McNally (2005) for detailed discussion of the relevant degree semantics:

$$
\llbracket \text { HOW COOL } \rrbracket=\lambda x \cdot \operatorname{cool}(\mathrm{x}) \gg \theta_{\text {cool }}
$$

It is now interesting to see that the [wh+Adj]-constituent with the reading in (24) features a root/non-root asymmetry that has also been observed in the licensing of other emphatic $w h$-constituents that are often used in surprise contexts. In particular, as first noted by Lasnik and Saito (1984), English appears to disallow a wh-word with the hell to remain in situ (e.g., *Who is in love with who the hell?; see Pesetsky 1987; Den Dikken and Giannakidou 2002). The same holds for a [wh+Adj]constituent such as (24) above. While $w h$-in situ in the degree reading sketched in (24) is not possible at all (25), it is perfect in the question reading (26); examples and judgments from Nye $(2009,19)$ :

(25) a. How cool is that!

b. * That's how cool!

(26) a. How cool is that?

b. That's how cool?

We thus see that $[w h+\mathrm{Adj}]$ in its degree reading must access the clausal left periphery, and I would like to adopt an approach that has been proposed by Bayer and Trotzke (2015) for other constructions of the wh-the-hell type: the whconstituent in (24) carries a root-sensitive feature of emphasis for intensity and therefore must be preposed to the relevant left peripheral projection of emphasis (see Sect. 2.1 above). Crucially, this projection-where, among other things, mirativity is encoded - cannot be at the level of illocutionary force. As already pointed out above, potentially any clause type can feature mirative interpretations, and so the relevant phrasal constituents are moved to the specifier of EmpP before 
they must move further for reasons of clausal typing. ${ }^{6}$ The difference between (25) and (26) is therefore that (26) lacks the extra movement to EmpP, and the [wh+ Adj]-constituent in that case merely moves to the left periphery to form a (nonechoic) question.

To sum up, the different interpretations (and thus also the different phrasal compositions inside the $w h$-phrases) are due to the left-peripheral options that are not shared between A-EXCs and wh-exclamatives on the one hand and interrogatives on the other hand, but rather are shared between any emphatic-fronting configuration (including declaratives) on the one hand and any non-emphatic speech act interpretations (lacking the intensifying effect of scalar readings) on the other hand. All in all, the differences of the wh-constituents in the question and the exclamation reading of strings like How cool is that can be accounted for by referring to a general strategy of emphatization in the left periphery-and not by referring to a distinct feature of wh-exclamatives shared with A-EXCs.

\subsection{Interim summary}

We can thus draw the preliminary conclusion that the exclamation reading of A-EXCs cannot be formally distinguished from their $w h$-interrogative counterparts by referring to syntactic properties that have been claimed to exclusively hold for wh-exclamatives. More specifically, the discussion above suggests that A-EXCs like How cool is that! cannot be analyzed as a subtype of wh-exclamatives because (i) they exhibit a different word order and do not share covert structure that distinguishes exclamatives from other sentence types (Sect. 2.1), and (ii) although their $w h$-constituent differs from the one in $w h$-interrogatives, both the degree semantics of the $w h$-constituent and the corresponding left-peripheral movement are features that are shared with emphatic readings of speech acts more generally (Sect. 2.2).

Given the discussion above, the general picture that emerges is that the exclamation component of A-EXCs cannot be considered (and analyzed) by features that have been proposed for $w h$-exclamatives. In the next section, I will therefore turn to the following two questions:

(Qi) Are there other non-syntactic cues (also in other languages) for the exclamation reading?, and

(Qii) If the syntax of A-EXCs is 'non-exclamative', what kind of role does it play in the interpretation of the speech act?

I will thus turn to the question of how the inversion syntax of A-EXCs contributes to their reading. I will approach both questions by comparing English to German. German is very useful for comparison because it has almost word-for-word equivalents to English configurations of the form How cool is that! Consider the examples in (27), the German counterparts of our key example How cool is that:

\footnotetext{
${ }^{6}$ In Sect. 3 below, I will in fact analyze A-EXCs as interrogatives and so this approach is fully compatible with my overall claim in this paper.
} 

a. Wie geil
ist das denn!
[intended: exclamation]
how cool (lit. 'horny') is that PART
'How cool is that!'
b. Wie geil ist das denn?
[intended: question]
how cool (lit. 'horny') is that PART
'How cool is that (e.g., on a scale from 1 to 10)?'

Although cases like (27a) are also a quite recent phenomenon in German, there are already two studies on this type of utterances (Finkbeiner 2015 and Auer 2016); both are framed within a construction-grammar account, highlighting that many linguistic dimensions of the utterance (27) accumulate to yield the exclamation reading: nature of the adjective, intonation, etc. Given that we have argued above that features of exclamative syntax cannot explain the exclamation reading of A-EXCs, it might be useful to look into this kind of literature to explore whether we observe reliable (non-syntactic) cues for the exclamation reading ( $\boldsymbol{Q} \boldsymbol{i}$ above).

Qii can also profitably be addressed by comparing German and English because in German both T-to-C movement and verb-final wh-configurations lacking this movement can express the speech act of an exclamation (i.e., there are both verbfinal AND V2 wh-exclamatives; see Sect. 3.2 below). Accordingly, the same syntactic option used to convey an exclamation (V2 wh-exclamatives) can also be used to perform the speech act of a regular wh-question. If the inversion syntax of A-EXCs in English has any semantic impact, and if the German counterpart in (27b) really expresses the same, then one would expect that German conveys this semantic impact by other means than word order-and this is exactly what we find: see Sect. 3.2 below.

\section{Connecting syntax to force: the special pragmatics of A-EXCs}

\subsection{Non-syntactic cues for the exclamation reading: English and German}

Since we have argued in Sect. 2.1 above that features of exclamative syntax cannot explain the exclamation reading of A-EXCs, it might be useful to look into some of the literature that has investigated some non-syntactic cues for the exclamation reading. Let us first look at the claim that the nature of the adjective might be a good candidate for disambiguating between the question and the exclamation reading of configurations like How cool is that.

In particular, Finkbeiner (2015) has argued for the German version of How cool is that! (Wie geil ist das denn!, see above) that the use of evaluative adjectives like cool or ingenious result in ambiguity, whereas a non-evaluative adjective such as basal usually results in an interpretation in terms of a regular wh-question (Finkbeiner 2015, 260). However, I think the disambiguating function of the adjective is overstated in Finkbeiner's (2015) study. While she might be right concerning the relative frequency of such adjectives, I hypothesize that any adjective compatible with a gradable reading can occur in A-EXCs, even those where a comparative form does not exist.

A corpus search in the Corpus of Web Based Global English (GloWbE; Davies 2013) indicates that adjectives such as wrong can occur in the exclamation reading 
without any problems. The GloWbE corpus is a resource that is particularly useful for searching expressions associated with informal, colloquial registers. The same holds for the German version of A-EXCs; see a parallel example from the DeReKo corpus in $(29)^{7}$ :

(28) I bought Saving Valor from Amber Kell (definitely DRM free) and I can read it on the Kobo app on my iPad, but I cannot download it from the site to my computer. How wrong is that? I haven't purchased from them since. < http://rabidreads.ca/2012/10/axe-to-grind-kobos-website.html >

(29) Ich finde es eine Frechheit, Änderungen unreflektiert (und vor allem auf I find it a cheek changes unreflecting and above all at einmal!!!) rückgängig zu machen. So macht ihr euch alle lächerlich. Nun once undone to make so make you yourself all ridiculous Now steht da wieder ,Einige Religionen[,] die aus dem Sufismus stand there again some religions that out.of the Sufism hervorgingen“(sinngemäß). Wie falsch ist das denn? originate.from OWTTE how wrong is that PART 'How cheeky to undo changes without thinking (and what's more, at once!). This way, you all embarrass yourself. Now, it says again "Some religions that originate from Sufism" (OWTTE). How wrong is that!' [DeReKo: attested at http://de.wikipedia.org/wiki/Diskussion:Dreadlocks: Wikipedia 2011 on March 1, 2019]

Given this observation, we can conclude that although in many cases the nature of the adjective might help in disambiguating between the two readings, this component of the wh-constituent is not a one-hundred percent reliable cue.

Another non-syntactic cue that suggests itself is intonation. Nye (2009) has pointed out that the main stress in the exclamation reading of How cool is that usually falls on the subject (30a; without evoking semantic contrast), whereas it is usually on the adjective in wh-questions (30b):

(30) a. How tall is THAT $=>$ !

b. How TALL is that $=>$ ?

c. HOW tall is that $=>$ ?

d. How tall IS that $=>$ ?/!

Nye (2009) does not provide intuitions about the other options in (30c) and (30d), but a small group of English native speakers $(n=5)$ I have consulted uniformly tells me that (30c) cannot really be interpreted as an exclamation, while (30d) could receive both interpretations (i.e., exclamation interpretation and regular $w h$ question). However, it is interesting to note that the heavy stress on the subject (here: a demonstrative) is not an obligatory component of the exclamation reading. In her empirical appendix, Nye $(2009,60-69)$ reports cases where both the personal

\footnotetext{
${ }_{7}$ If not stated otherwise, the internet links in this paper were last accessed on September 30, 2020.
} 
pronoun (31a) and the expletive (31b) it can appear as a subject in such exclamations, although it cannot bear heavy stress:

(31) a. How big is it!

b. How sweaty is it today!

c. How big IS it!

d. How sweaty IS it today!

Given what I have said above, the main accent would therefore most probably fall on the auxiliary when the speaker intends the exclamation reading in these cases $(31 \mathrm{c} / \mathrm{d})$.

Be that as it may, as soon as a d-pronoun is present in those configurations, we often observe that it is heavily stressed, which is usually not the case in the whquestion interpretation. This intonational difference is also confirmed empirically by Repp's (2015) recent work on comparing the acoustics of wh-questions and verbsecond wh-exclamatives in German.

Although not concerned with wh-configurations that contain $w h+$ Adj in Spec$\mathrm{CP}$, this study clearly shows that d-pronouns are more prominently stressed in $w h$ exclamatives, and that this stress pattern, although not obligatory, can thus serve as a cue for the exclamation interpretation in many cases. Note that just like we have seen for English in (30) above, there is also a preferred stress pattern for the exclamation interpretation of A-EXCs in German. In particular, the version where the strong (subject) d-pronoun is accented is the variant that most clearly signals the exclamation reading $(32 b)$ :

(32) a. Wie GEIL ist das denn $=>$ ?/!

b. Wie geil ist DAS denn $=>$ !

c. WIE geil ist das denn $=>$ ?

d. Wie geil IST das denn $=>$ ?/!

Supporting this idea, Auer $(2016,73)$ claims that in the exclamation interpretation, the main accent in fact must be placed on the demonstrative. This intuition can be related to the recent experimental work by Repp (2015) above, who shows that d-pronouns are more prominently stressed in wh-exclamatives, and that this stress pattern, although not obligatory can thus serve as a cue for the exclamation interpretation in many cases. However, as indicated in (32a), the exclamation interpretation can also arise in cases where the adjective is heavily stressed. This is in line with older (non-experimental) claims by Altmann (1993) that the so-called exclamative accent in German wh-exclamatives often occurs on the scalar expression. Altmann (1993) also claims that the exclamative accent may also be carried by the verb in V2 exclamatives, similar to what is indicated in (32d).

Given all these different hypotheses, the only two stress patterns that might display a preference for one of the two readings are $(32 b=$ exclamation reading $)$ and (32c=regular- $w h$-question reading). This is also in line with what has been found in the production studies by Repp (2015): stressing the d-pronoun (and not stressing of the verb in second position) is the most reliable cue for the exclamation interpretation, while stressing the wh-element most of the time is associated with 
the question interpretation. ${ }^{8}$ We can thus conclude that the exclamation component of A-EXCs can indeed be signaled by both intonation and the respective nature of the adjective, but that these non-syntactic cues for this particular reading are not one-hundred percent reliable cues taken by themselves. However, taken together they can 'add up' and reliably result in the exclamation interpretation. This might be the reason why the German versions of A-EXCs have so far only been investigated from a constructionist perspective; this framework lends itself best to capture those cumulative effects coming from different linguistic levels/domains. In what follows, I will look at another non-syntactic means of A-EXCs in German that, according to my approach, plays an important role in the interpretation of the utterance: the distribution of modal particles (Sect. 3.2). Based on this discussion, Sect. 3.3 will then turn to the comparison with English again, and I argue that the word order in English A-EXCs actually impacts their reading, and that this impact can be analyzed along the lines of what I will now say about the modal particles in the next section.

\subsection{German A-EXCs and the distribution of modal particles}

As already mentioned at the end of Sect. 2 above, in German both T-to-C movement (33a) and verb-final $w h$-configurations lacking this movement (33b) can express the speech act of an exclamation. Accordingly, the same syntactic option used to convey an exclamation can also be used to perform the speech act of a regular $w h$-question (34):

(33) a. Wie vergesslich ist Oma aber auch seit letztem Jahr geworden ist! how forgetful is grandma PART sincelast year gotten is

b. Wie vergesslich Oma aber auch seit letztem Jahr geworden ist!

(34) Wie vergesslich ist Oma denn/wohl seit letztem Jahr geworden ist? how forgetful is grandma PART/PART since last year gotten is 'How forgetful has grandma gotten since last year?'

In our context it is important to note that the respective readings can also be indicated by the non-obligatory exclamative (33) and question particles (34), which only work in their respective speech acts. Given that German features particles like that, let us now focus on the obvious difference between English How cool is that and German Wie geil ist das denn: the presence of the modal particle denn (lit. 'then'); on German modal particles in general, see, for example, Meibauer (1994); Grosz (to appear); and many others.

Finkbeiner (2015) points out that the modal particle can also be left out when the demonstrative is heavily stressed and thereby evokes the exclamatory reading.

\footnotetext{
${ }^{8}$ There is also older experimental work on the intonation of exclamatives in German (most notably by Batliner 1988). Unfortunately, these studies only compare the prosody of verb-second declaratives and exclamatives and thus do not investigate the difference that is relevant for our structures above, namely that between verb-second $w h$-questions and (verb-second) $w h$-exclamatives. The study by Repp (2015) is the first study that directly addressed this question for German; however, there is of course more cross-linguistic work showing that the distinction between $w h$-interrogatives and $w h$-exclamatives by means of intonation can be quite robust in some languages (see, e.g., work on Hungarian by Gyuris and Mády 2013).
} 
However, although not obligatory, the presence of a modal particle is highly preferred in the German versions of A-EXCs. Based on a corpus search in the DeReKo corpus, Auer (2016) found 565 hits of the form Wie ADJ KOP DEM-PRON (denn) and reports the ratio of 7:1 for the presence of the modal particle in the A-EXC interpretation. It is thus reasonable to look in more detail at what kind of modal particles can occur in German A-EXCs because their distribution might tell us something about the exact discourse function of these utterances.

Let us first look at Table 1, which is based on Thurmair's (2013) overview of modal particles in different sentence types and summarizes the distribution of particles occurring in $w h$-exclamatives and wh-questions in German:

Table 1 Distribution of modal particles in wh-exclamatives and wh-questions

\begin{tabular}{ll}
\hline wh-V2 questions & $\begin{array}{l}\text { wh-verb-final } \\
\text { exclamatives } \\
\text { wh-V2 exclamatives }\end{array}$ \\
\hline bloß & aber \\
bitte & aber auch \\
denn & bloß \\
eigentlich & doch \\
nur & nur \\
schon & vielleicht \\
wohl & \\
$(. .)$. & \\
\hline
\end{tabular}

In what follows, I will argue that the set of particles that can occur in German A-EXCs does not correspond to an intersection between particles that are licensed in $w h$-questions and particles that occur in exclamatives. Rather, the special pragmatic function of A-EXCs is signaled by a dedicated class of modal particles.

To see this, let us start at a very general level. As a first approximation, German modal particles tell us something about our general inventory of basic (or 'major') sentence types. It is often claimed that sentence-type sensitivity is a defining property of modal particles (e.g., Thurmair 2013). To illustrate, consider the following contrasts:

(35) a. Wo fährt er denn hin?

where travels he PART to

'Where is he traveling to?'

b. * Fahr denn nach Barcelona!

travel PART to Barcelona

'Travel to Barcelona!'

c. * Er fährt denn nach Barcelona.

he travels PART to Barcelona

'He is traveling to Barcelona.'

(35) demonstrates that modal particles are restricted to specific sentence types. In our case, denn can only occur in interrogatives (35a) and not in imperatives (35b) or declaratives (35c). However, even within a particular sentence type, modal particles 
are confined to specific use conditions. Look at a prominent example by König (1977, 119):

(36) CONTEXT: A wakes up B and A asks:

\# Wie spät ist es denn?

how late is it PART

'What time is it?'

According to the literature, one component of denn is to indicate that the information that is asked for by the speaker is part of a discourse that has already been established between the speaker and the addressee. The example in (36) illustrates that questions featuring denn are infelicitous when the addressee (here: $\mathrm{B}$, who just woke up) lacks a context (read: common ground) in which to interpret the question. However, recently it has also been noted in the literature (e.g., Theiler 2018) that denn-questions can actually be asked out of the blue:

(37) CONTEXT: Someone asking a passerby:

Wo ist denn hier der Bahnhof?

where is PART here the train-station

'Where is the train station here?'

It has thus been suggested that the obligatory relation to the discourse that denn expresses must thus be conceived in broader terms, and that denn rather is an abstract 'discourse-navigating device' (Zobel and Csipak 2017) that 'helps interlocutors with navigating a discourse' (Theiler 2018). In recent work on the Dutch cognate of German denn, the particle dan, Trotzke and Haegeman (in press) suggest picturing the abstract discourse function of the German particle denn as follows:

(38) Wo ist denn der Bahnhof?

where is PART the train-station

'Where is the train station?'

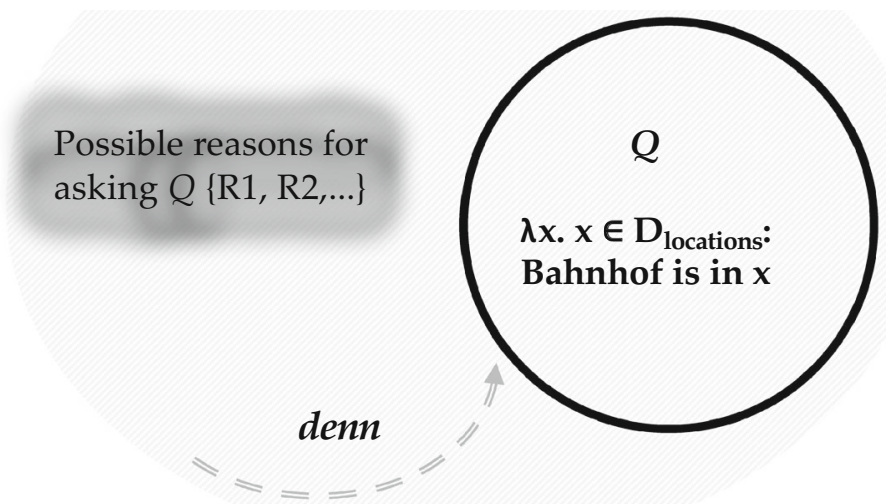

Fig. 1 denn navigating between the 'ground' (the reason(s) for posing the question) and the 'figure' (the question/the highlighted, focused part of the question) 
The main point by Trotzke and Haegeman (in press) is that given their data on both Dutch dan and German denn, they take the informal paraphrase of denn as a 'discourse navigating device' seriously by endorsing a more narrowly spatial interpretation of denn. That is, they conceive denn as a navigation device between figure and ground, and an utterance like (38) would encode the meaning depicted in Fig. 1, where denn navigates between the 'ground' (the reason(s) for posing the question) and the 'figure' (the question/the highlighted, focused part of the question). Trotzke and Haegeman (in press) argue that such a core meaning of denn is supported by its grammaticalization path that has been postulated in the diachronic literature (see Abraham 1991; Wegener 2002):

(39) localistic $>$ temporal $>$ logical $>$ illocutive/discourse functional (Abraham 1991, 373)

In particular, the particle denn can be derived from Idg. root *to, which expresses a deictic meaning. OHG dannelthanne (cf. English then) first was a locative adverb and only later became a temporal adverb.

Be that as it may, the data above show that modal particles are not only restricted to different sentence types and their general illocutionary potential. Rather, the use of modal particles is also confined to certain illocutionary subtypes expressed by the same sentence type and can teach us something about the use conditions of these subtypes.

In other words, the German versions of A-EXCs are interesting because the occurrence of modal particles such as denn can help identify the discourse meaning and exact use conditions of these utterance types. Based on the sketch above, we can say that denn signals reference to the common ground between speaker and addressee. Now, German A-EXCs can also contain other particles that share some crucial features with denn. Here are some examples featuring the particle eigentlich (lit. 'actually'):

(40) Aber zurück zum Clip: Wie geil ist der eigentlich? Ich war but back to.the clip how cool is it PART I was stolz wie Oskar, als er veröffentlicht wurde. pride like Oscar when it released was 'But back on the clip: How cool was that? I was as proud as a peacock when it got released.' < attested at http://www.pleasuremag.com on March 1, 2019> 


$\begin{array}{lllllllll}\text { (41) Meine } & \text { Familie und } & \text { Freunde waren entsetzt und jeder } & \text { hat } & \text { sich } \\ \text { my } & \text { family and Friends } & \text { were shocked } & \text { and } & \text { everyone has } & \text { themselves } \\ \text { gefragt } & \text { "Wie } & \text { blöd ist der } & \text { eigentlich?!“. } & \text { Denn } & \text { ich } & \text { stand nun } \\ \text { asked } & \text { how } & \text { stupid is } & \text { he } & \text { PART } & \text { because I } & \text { stood now } \\ \text { da, } & \text { ohne } & \text { Abschluss mit } & \text { abgebrochener } & \text { Berufsausbildung. } & & \\ \text { there without degree } & \text { with incomplete } & \text { vocational.training } & & \end{array}$

'My family and friends were shocked, and everyone asked themselves: How stupid is he! Because now I stood there without a degree and with incomplete vocational training.'

< attested at https://www.muskelkater-giessen.de on March 1, 2019 >

Note that eigentlich is in principle ambiguous between a modal-particle and an adverb reading, which is typical for many German particles. One way to clearly distinguish the two readings is placing stress on eigentlich, since modal particles in questions cannot be stressed:
a. Wie blöd ist der eigentlich!
how stupid is he PART
'How stupid is he!'
b. Wie blöd ist der EIgentlich?
how stupid is he actually
'How stupid is he actually?'

In the examples (40) and (41) above, eigentlich clearly occurs in its particle-reading and thus could not receive heavy stress. Another particle occurring in German versions of A-EXCs is bitte (lit. 'please') 9 :

(43) Omg! Ich brauch dieses Hausschwein von Marcel Wanders! Wie geil OMG I want this squealer by Marcel Wanders how cool ist das bitte?!

is that PART

'OMG! I really want this squealer by Marcel Wanders! How cool is it!' < attested at http://www.imgrum.net on March 1, 2019>

\footnotetext{
9 As in other speech acts, particles can also be stacked in How cool is that!, e.g.,

(i) 1LIVE holt Ed Sheeran \& Coldplay zum „1LIVE-Radiokonzert“... ILIVE brings Ed Sheeran \& Coldplay to.the "ILIVE Radio Concert" wie geil ist das denn bitte?!!!

how cool is that PART PART

'1LIVE will host Ed Sheeran \& Coldplay at the 1LIVE Radio Concert... How cool is that!' $<$ http://dreiraumhaus.de/2014/04/17/1live-radiokonzert-edsheeran-coldplay >
}

My intuition is that such stacking merely emphasizes the same meaning that can be expressed by using only a single particle, and thus that stacking does not add a new meaning component to the construction. As for the syntactic side of this issue, ordering constraints exist just as in the case of regular questions (cf. *bitte denn). Note that in regular $w h$-questions (since more diverse particles can be used) stacking can indeed modify the meaning of the whole configuration (e.g., Wo wird er denn schon sein? 'After all, where might he be?' both features pointing to a common ground (=denn) and a rhetoricity component (=schon). 
(44) $[\ldots]$ und freitag fragt er $\mathrm{K}$ ob wir in $\mathrm{fb}$ befreundet sind?! hallo?! and Friday asks he $K$ whether we in FB friends are hello wie blöd ist das bitte?!

how stupid is that PART

'[...] and Friday he asks $\mathrm{K}$ whether we are friends on Facebook?

Come on! How stupid is that!'

$<$ attested at http://www.maedchen.de on March 1, 2019>

Crucially now, we observe that German A-EXCs can only contain a subset of particles that can occur in German wh-questions (see Thurmair 2013 and Table 1 above). For instance, consider the cases of nur (lit. 'only') and schon (lit. 'already'). The particle nur does not refer to the common ground between speaker and addressee in the way denn, eigentlich, and bitte do. In (45a), nur signals that the speaker has tried a number of times to find an answer, but without success (see Dörre and Trotzke 2019 for semantic details). Similarly, the particle schon also differs from the particles introduced above because it serves to mark rhetorical questions (45b); see Bayer and Obenauer (2011); Trotzke and Turco (2015):

(45) a. Wie geil ist das nur?

how cool is that PART

'How cool is that? (I have already asked myself several times.)'

b. Wie geil ist das schon?

how cool is that PART

'After all, how cool is that? (Not very cool!)'

Both particles are ruled out in the A-EXC interpretation, as (46) illustrates. Finkbeiner $(2015,247-248)$ provides empirical evidence from Google searches that confirms this impression: the particles wohl, nur, blo $\beta$ are virtually excluded from German How cool is that.

(46) CONTEXT: A is completely amazed at the musician's performance and would like to share his amazement with B who is attending the show together with A. A exclaims:

a. ?? Wie geil ist das nur! how cool is that PART

'How cool is that? (I have already asked myself several times.)'

b. ?? Wie geil ist das schon! ${ }^{10}$ how cool is that PART

'After all, how cool is that?' (Not very cool!)'

On the other hand, denn and eigentlich do not belong to the class of exclamative particles. These particles, which frequently occur in A-EXCs, are restricted to interrogative syntax and are thus incompatible with $w h$-exclamatives:

\footnotetext{
${ }^{10}$ Note that schon can only be used felicitously in the exclamation interpretation if schon is interpreted as the adverb 'already'. In this case, it can also receive heavy stress.
} 
(47) *Was wir denn/eigentlich für blöde Kerle sind! what we PART/PART for stupid guys are (intended: 'What stupid guys we are!')

This is corroborated by Thurmair's $(2013,638)$ comprehensive overview, which mentions that the following particles (in bold) are licensed in wh-exclamatives (this list is consistent with the inventory mentioned by d'Avis 2016, 162):

(48) Was wir doch/aber auch/bloß/nur für blöde Kerle sind! what we PART/PART/PART/PART for stupid guys are 'What stupid guys we are!'

As has also been observed for the 'minor' sentence type of optative constructions (see Grosz 2012), the set of modal particles is relatively small in exclamatives, and the literature has not proposed any significant meaning differences depending on what kind of particle is used (however, see some remarks on subtle differences in Thurmair 1989, 190-194). One could speculate that the set is rather small because wh-exclamatives have enough distinct properties and thus do not depend on modal particles as cues as much as other sentence types do. As already mentioned above, specific lexical markers (such as what a or was für in German), together with exclamative intonation, are clear indications of an exclamatory interpretation.

Let us summarize our observations by looking at Table 2, a revised version of Table 1. The table indicates that the set of possible particles in German A-EXCs does not correspond to an intersection between particles that are licensed in whquestions and particles that occur in exclamatives. Rather, the special pragmatic function of A-EXCs is signaled by a dedicated class of modal particles, namely denn, eigentlich, and bitte. The question thus arises whether the question particles schon, wohl, and nur/blo $\beta$ share a common property that excludes them from the A-EXC reading on the one hand, and if, on the other hand, denn, eigentlich, and bitte share a property that explains why they are felicitous in the A-EXC reading.

Table 2 Distribution of modal particles in German A-EXCs (in bold)

\begin{tabular}{ll}
\hline wh-V2 questions & $\begin{array}{l}\text { wh-verb-final } \\
\text { exclamatives } \\
\text { wh-V2 exclamatives }\end{array}$ \\
\hline bloß & aber \\
bitte & aber auch \\
denn & bloß \\
eigentlich & doch \\
nur & nur \\
schon & vielleicht \\
wohl & \\
$(. .)$. & \\
\hline
\end{tabular}


Let us first turn to the question of what common property the particles schon, wohl, and $n u r / b l o \beta$ share that excludes them from A-EXCs. I already mentioned above that schon can be used to signal that a $w h$-interrogative should be interpreted as a rhetorical question. Note that particles like schon are not obligatory to form 'special' (here: rhetorical) questions; but once these particles are used, they serve as reliable 'communicative cues' (Grosz 2014) to indicate to the addressee that the interrogative should be interpreted as a rhetorical question:

(49) Wie hoch ist das schon?

how tall is that PART

'After all, how tall is that?' (Not very tall!)'

One of the main characteristics of a rhetorical question is that an answer to that question is not expected. Now, how do wohl and nur/blo $\beta$ connect to this type of interpretation that licenses the use of schon? Consider again an example featuring these particles:

(50) Wie hoch ist das wohl/nur/bloß?

how tall is that PART/PART/PART

'How tall is that?'

Note that it is striking that exactly these three particles (and only these) are obligatory in wh-verb-final sentences in German that express a deliberative and/or speculative interpretation (see Truckenbrodt 2013, 241):

$$
\begin{aligned}
& \text { a. Wen sie wohl/nur/bloß mag? } \\
& \text { who she PART/PART/PART likes } \\
& \text { 'Who does she like?' }
\end{aligned}
$$

b. \# Wen sie mag?

[only possible reading: echo question]

These deliberative questions are typically not addressee- but rather self-oriented. Accordingly, speakers do not expect to receive a straight answer and are mulling over something that is currently uppermost in their mind. What these questions and the use of the particles wohl, nur, and blo $\beta$ thus share with schon in rhetorical questions is that they express:

'that the obligation to answer the question is suspended.'

(common discourse feature of German particles wohl, nur, bloß, and schon)

Let us now look at the particles that are felicitous (if not virtually obligatory) in How cool is that (i.e., denn, eigentlich, and bitte). I already referred to the basic meaning of denn above by citing the prominent example from König (1977), repeated here for convenience: 
(52) A wakes up B and A asks:

\# Wie spät ist es denn?

how late is it PART

'What time is it?'

As already highlighted above, denn indicates that the reason for posing the question can be found in the current discourse context (visualized in Fig. 1 above). (53) is infelicitous because the addressee (B, who just woke up) lacks a discourse context in which to interpret the question. Note now that eigentlich is infelicitous for the same reason; it requires that the addressee is aware/has knowledge about the current discourse context:

(53) A wakes up B and A asks:

\# Wie spät ist es eigentlich?

how late is it PART

'What time is it?'

This observation is in accordance with work by Eckardt (2009) who highlights that unstressed eigentlich (i.e., the particle use of eigentlich) is infelicitous in questions in certain discourse-initial environments (see Eckardt 2009, 104-105). Concurring observations have also been made for Dutch eigenlijk (van Bergen et al. 2011), namely that this particle, in van Bergen et al.'s terms, expresses that the speaker is aware of assumptions shared with the addressee.

Crucially now, the common semantics of denn and eigentlich cannot be the whole story of why these particles are felicitous in German A-EXCs. Turning to the particle bitte, we observe that this particle is perfectly fine in the context above:

(54) A wakes up B and A asks:

Wie spät ist es bitte?

how late is it PART

'What time is it?'

Zimmermann (2009) points out that bitte is only infelicitous when the context is such that neither speaker nor addressee are in a position to answer the question (and even B, who just woke up, is at least able to answer the question, if not necessarily prepared to answer at that very moment). To see this, look at the following examples taken from Zimmermann $(2009,57)$; note that the point of verb-final $o b$ interrogatives $(55 \mathrm{~b})$ is to express mutual ignorance:

(55) A and B are lost in the woods while hiking. A asks B:

a. \# Welches ist bitte der Weg aus dem Wald?

which is PART the way out the forest

'What would be the way out of the woods?'

b. \# Ob das bitte der richtige Weg ist?

if this PART the right way is

'Will/Would this be the right way?' 
The particles denn and eigentlich are ruled out in the same context:

(56) a. \# Welches ist denn/eigentlich der Weg aus dem Wald? which is PART/PART the way out the forest

'What would be the way out of the woods?'

b. \# Ob das denn/eigentlich der richtige Weg ist?

if this PART/PART the right way is

'Will/Would this be the right way?'

We can thus conclude that the common property of denn, eigentlich, and bitte is that they are only licensed in a context where

'A believes that B is able to supply an answer to the question.' (common discourse feature of German particles denn, eigentlich, and bitte)

This basic component of the particles' meanings has already been formulated for denn by Zobel and Csipak (2017), but the examples above illustrate that it also holds for eigentlich and bitte. In other words, only those particles that express that the addressee is able to supply the requested response, given an already established common ground between speaker and addressee, are felicitous in A-EXCs. Note that the use of schon, wohl, and nur/blo $\beta$ are not subject to the same felicity condition: in the case of wohl and $n u r / b l o \beta$, for instance, the speaker can only hope that $\mathrm{B}$ is able to supply an answer, but the point of using nur/blo $\beta$ is that A cannot be sure about B's ability to provide an answer (in fact, both particles leave open the possibility that nobody, including $\mathrm{A}$ and $\mathrm{B}$, can answer the question).

Interestingly, languages that do not feature modal particles often express the meaning contribution of particles like denn, eigentlich, or bitte by other linguistic means/phrases. These alternative lexical or phrasal means also convey that the speaker and addressee are already part of a shared discourse, and that their common ground allows for the conclusion on the part of the speaker that the addressee is perfectly able to supply an answer to the question. Consider the following selection of English examples gathered via Google search:

(57) Heck, they can play with the software themselves to add whatever they want to the lifestyle search. I mean, come on, how cool is that? [...]" $<$ attested at http://blog.spatialmatch.net on March 1, 2019>

(58) There is no project that upstream wants to implement this hack, and finally what is cooking, a brand new font! Now, how cool is that! $<$ http://gregdekspeaks.wordpress.com/2010/07/29/red-hat-16-canonical-1 > 
(59) At INVERS, I developed an app with which I can open my car... I mean, how cool is that?!

$<$ https://invers.com/company $>$

(60) Seriously, how cool is that? Using a camera and a projector to learn how to play bass guitar! Augmented Reality here we come $<$ https://www.reddit.com/r/technology/comments/94yr6/seriously_ how_cool_is_that_using_a_camera_and_a/ >

(61) Well Now, How Cool is That? Today was my first time to enter the Camera Critters meme.

$<$ http://snowbirdblogspotcom.blogspot.com/2008/09/well-now-howcool-is-that.html >

Of course, these examples and observations are only preliminary and therefore deserve further in-depth investigation. Importantly, these preceding lexical/phrasal means to indicate that the speaker has reasons for assuming that the addressee shares assumptions about the ongoing discourse and is thus able to provide a response cannot felicitously occur with the exclamative (=verb-final) counterparts of A-EXCs:

(62) a. ?? Seriously, how cool that is!

b. ?? I mean, come on, how cool that is!

c. ?? Well now, how cool that is!

Note that discourse-marking elements like in (57)-(61) are also often used in German in addition to modal particles. For example, example (44) above additionally contained a special use of German Hallo, preceding the utterance. It is pronounced with a rising contour [/] and also exists in English when used to express indignation and/or annoyance; compare the following German example:

(63) Ich bin hier wohl im falschen Film! Hallo! Geht's noch?

I am here PART in.the wrong movie hello goes=it still

'I guess I'm in the wrong movie here! Hello? Are you crazy?'

$<$ https://www.bod.de/autorenpool/meinung-gefragt-t16661,start,15.html>

It would be odd if this element would be used as preceding an exclamative, since it conveys a certain subjective shakiness on the part of the speaker, which is in conflict with strong and thus confident evaluations expressed by exclamatives. In a sense, elements such as Hallo!?, seriously?!, etc. are anchored with the addressee and elicit a certain kind of answer (a serious one, a straight one, etc.). It is thus no surprise that this 'interrogative flip' is incompatible with exclamatives (on this notion, see Tenny 2006). 
Let us take stock. Although A-EXCs and wh-exclamatives in both English and German share their exclamation component (see Sect. 2 above), looking at the German data suggest that A-EXCs ask for affirmation by the addressee to a greater extent. In particular, this is indicated by response-evoking modal particles in German (and analogous discourse marking elements in English, as the data set above suggests). My terminological distinction, already introduced at the outset of this paper, is thus corroborated by the data discussed above: A-EXCs aim at a reaction by the addressee, whereas exclamatives, on the other hand, do not aim at an affirmation (or, for that matter, at an objection) on the part of the addressee. Rather, the expressive content ('that the speaker is surprised about $p$ ') is a subjective emotion on the part of the speaker, and the addressee can of course affirm or object to this emotion, but the utterance of an exclamative does not require such a reaction or response by its linguistic form. We thus find two subtypes in the domain of exclamation speech acts (EXC): one that asks for affirmation on the part of the addressee (A-EXC) and one that does not, and which I would like to call 'speakeroriented' exclamations (or S-EXC for short).

This is in line with what has recently been proposed for another class of inversion exclamatives in English. In particular, while Taniguchi (2017, 127135) claims that all exclamatives are only about speaker commitment (and thus 'not up for discussion'), Jamieson (2018) has shown that at least negative inversion exclamatives must also involve some connection with (the evidential situation of) the addressee. Consider the following example from Jamieson (2018, 179):

(64) $\mathrm{S}$ is on the phone to $\mathrm{A}$, and is telling $\mathrm{A}$ about their new cat. S just picked up the cat that day. $\mathrm{S}$ says:

\# Isn't it cute!

(64) cannot be explained by a model like Taniguchi's (2017) where the speakerwhen uttering any type of exclamative-updates the Common Ground without inquiring what the addressee thinks. We thus see that there are even more syntactic configurations that support the idea that we must distinguish between A-EXCs and S-EXCs, as introduced above. I must admit that I do not have an explanation for why cases like How cool is that and negative inversion exclamatives behave similarly in this regard. Note that it cannot be due to the inversion property because positive inversion exclamatives (i.e., Boy, is it cute!) would be totally fine in a context like (64). My hunch is that for the exclamatives with polar question syntax, the answer lies in the non-degree interpretation of negative inversion exclamatives (as discussed in length by both Taniguchi 2017 and Jamieson 2018). However, as for the $w h$-cases of A-EXCs, I will argue that their addressee-orientation can indeed 
be derived from their word order. ${ }^{11}$ Accordingly, in order to capture the full pragmatics of A-EXCs, we have to complement the idiosyncratic properties sketched in Sect. 3.1 and often highlighted in the constructionist literature with relevant aspects of compositional syntax.

\subsection{The pragmatics of A-EXCs and the V-to-C property}

Finkbeiner (2015) points out that, in contrast to regular wh-questions, A-EXCs are not conveying the expectation that the addressee should provide an answer. Crucially, however, she also hypothesizes something along the lines mentioned in the last section above: that A-EXCs come with an obligation to react to them. ${ }^{12}$ Related to this characterization, she postulates that A-EXCs are essentially evaluative acts: that is, they can express different evaluations, depending on what kind of adjective is used; the following examples are given by Finkbeiner (2015, 267; translations are mine) and are based on her data gathered from Google:
a. Wie smart ist das denn!
how smart is that PART
'How smart is that!'
b. Wie krank ist das denn! how sick is that PART
'How sick is that!'
[contempt]
c. Wie lecker ist das denn! how yummy is that PART 'How yummy is that!'
[admiration]
[appreciation]

Finkbeiner (2015) points out that evaluative acts in general are characterized by the addressee-oriented goal to prompt the addressee to share the evaluation and/or to recommend or advise against something. I agree with Finkbeiner (2015) that this addressee-oriented pragmatics holds for cases like (65). It is not clear to me, however, if and how A-EXCs (65b) then differ from other wh- or also nominal exclamations (66a) because such a difference is what Finkbeiner (2015) claims in the first place:

\footnotetext{
11 Another fact that supports the hypothesis that the two phenomena probably involve two very different explanations is that the distribution of German modal particles in negative polar exclamatives in German is not the same as in the wh-versions of A-EXCs. In particular, both the particle bitte and eigentlich are clearly out in those configurations, and only denn seems to be grammatical, probably due to its highly abstract function; see Fig. 1 above.
(i) Ist das denn (*bitte/*eigentlich) nicht schön! is that PART not beautiful 'Isn't it beautiful!'

12 The hypothesis that speakers use A-EXCs when they aim at a response by the addressee is further substantiated in Finkbeiner's (2015) work by her observation that this construction is particularly frequent in sharing activities in social-media contexts. The point of using this construction in this context (often as a headline) is to draw the attention of other users to a particular content and get them to share it. Since reactions and further comments by other users are hoped for, A-EXCs seem to be a suitable means to both get attention (the exclamation component) and ask for a response, a comment, or a 'like'.
} 
(66) a. What a tall building!/Was für ein hohes Gebäude!

b. How tall is that building!/Wie hoch ist das Gebäude denn!

It is not obvious that the exclamations in (66a) aim at a reaction by the addressee although they should also be classified as 'evaluative acts', according to Finkbeiner's (2015) discussion. In what follows, I will show that in fact only A-EXCs of the form given in (66b) clearly display such a discourse function.

Importantly, this is supported by both the distribution of modal particles discussed in the last section and the property of V-to-C movement of such cases. In particular, while the exclamation component of such questions (discussed in Sect. 2) is not triggered by word order, its special interpretation of asking for a response from the addressee is. To show this, I will adopt the theory of $\mathrm{V}$-to-C movement by Truckenbrodt (2006), certainly one of the most detailed approaches to the semantic and pragmatic effects of this syntactic operation.

Let us start by looking at the following German main clauses. In (67a), involving stress-bearing $J A$, the main clause does not exhibit V-to-C movement, while (67b) features this syntactic operation (see Truckenbrodt 2006, 269):
a. Dass du (JA) das Fenster öffnest! that you (PART) the window open '(Don't forget to) open the window!'
b. Du öffnest das Fenster.
you open the window
'You're opening the window.'

Although the verb is inflected for second person singular in both (67a) and (67b) and although both examples denote a proposition, (67a), lacking $\mathrm{V}$-to-C movement, cannot express an assertion, but is used here as a directive speech act. According to Truckenbrodt's (2006) theory, the difference between these two word orders can be captured in terms of an epistemic component residing in the $\mathrm{C}$-domain of the clause (in what follows: Epist). To see this, consider the following speech act paraphrases of a declarative (68a) and a corresponding interrogative (68b), both featuring V-to-C movement (see Truckenbrodt 2006, 264-265); S=speaker; A=addressee:

(68) a. Der Peter hat das gemacht.

the Peter has this done

'Peter has done this.'

Speech act paraphrase: ' $S$ wants from A that it is common ground that Peter has done this.'

b. Hat der Peter das gemacht?

has the Peter this done

'Has Peter done this?'

Speech act paraphrase: ' $S$ wants from $A$ that it is common ground whether Peter has done this.' 
Note that Truckenbrodt postulates that the interpretations of both declaratives (68a) and interrogatives (68b) always have the common ground as the "epistemic desideratum', in his terms. Accordingly, in both cases of V-to-C movement above, the feature Epist yields the meaning component it is common ground that/ whether...' Note also that Truckenbrodt (2006) conceptualizes “all sentential speech acts as volitional on the part of the speaker [...] S wants something, wishes for something, invites A to do something etc." (Truckenbrodt 2006, 263-264). Given this deontic conception of the speaker's intentions (abbreviated as 'Deont ${ }_{\mathrm{s}}$ '), Truckenbrodt argues that the C-head contains a set of features that can be formally captured as a 'context index' (Truckenbrodt 2006, 265):

(69) In a context index $\left\langle\right.$ Deont $_{\mathrm{S}}(, \mathrm{x})(,\langle$ Epist $\left.\rangle)\right\rangle$ in $\mathrm{C}$

\section{a. Epist is present iff}

(i) $\mathrm{C}$ contains a finite verb with indicative or Konjunktiv II or

(ii) $\mathrm{C} / \mathrm{CP}$ is marked $[+\mathrm{WH}]$;

b. $\mathbf{x}=\mathbf{A}$ iff $\mathbf{C}$ contains a finite verb with person inflection.

We can easily see why Truckenbrodt includes (ii) in (69a): root interrogatives without V-to-C movement but with $[+\mathrm{WH}]$ can feature the epistemic interpretation (Truckenbrodt 2006, 274), in contrast to cases like (67a) above.

(70) $[+\mathrm{WH}]$, no V-to-C movement

$\mathrm{Ob}$ er immer noch kubanische Zigarren mag?

whether he always still Cuban cigars likes

'I wonder whether he still likes Cuban cigars?'

' $S$ wants it to be common ground whether he still likes Cuban cigars.'

Although [+WH] configurations can thus have Epist without V-to-C movement, these structures lack the addressee-oriented component 'from A', which is present in the interpretations of (68a) and (68b) above. In other words, questions like (70) are typically used when the speaker assumes mutual ignorance, that is, when he does not expect the addressee to know the answer; see also our discussion of Zimmermann's (2009) example in Sect. 3.2 above. Hence, according to Truckenbrodt, $[+\mathrm{WH}]$ alone cannot provide the value ' $A$ ' for ' $\mathrm{x}$ '. Only if $\mathrm{V}$-to-C is present, the value $\mathrm{A}$ can be provided in the context index of the C-domain.

Coming back to our exclamatory cases, I agree with Truckenbrodt (2006) that exclamatives are outside this deontic-epistemic system. As I already indicated in Sect. 2, various sentence types can receive an exclamatory interpretation by intonational, lexical means, and emphatic fronting of various phrasal constituents to the left periphery. And, at first sight, also our cases of A-EXCs are a good example 
of this for the most part unrestricted situation, given that the heavy stress on the subject is prototypically associated with the exclamation interpretation:

\section{(71) a. How tall is THAT!}

b. How TALL is that?

However, while wh-exclamatives have neither Deont ${ }_{\mathrm{S}}$, Epist, nor A, and thus do not necessarily feature V-to-C movement (as is the case in English and German), utterances of the form How cool is that! or Wie geil ist das denn! cannot be characterized as wh-exclamatives, although they share the exclamation component with their exclamative counterparts. Once we acknowledge that A-EXCs slightly differ in their pragmatics from $w h$-exclamatives (indicated in German by a dedicated set of particles; see Sect. 3.2 above), it makes sense in the light of Truckenbrodt's observations that they necessarily involve V-to-C movement.

At this point, we have to recall from Sect. 3.2 above that $w h$-exclamatives in German can also feature T-to-C movement. Consider, again, the following examples:

(72) Wie vergesslich ist Oma aber (auch) seit letztem Jahr geworden ist! how forgetful is grandma PART since last yeargotten is 'How forgetful grandma has gotten since last year!'

(73) Wie vergesslich ist Oma denn/wohl seit letztem Jahr geworden ist? how forgetful is grandma PART/PART since last year gotten is 'How forgetful has grandma gotten since last year?'

German thus features structurally ambiguous wh-configurations with T-to-C movement. However, the structures in (72) and (73) can be disambiguated by specific particles: in (72), the exclamative particle aber (auch) clearly signals that the structure should be interpreted as an exclamative, and thus the particle serves as a 'communicative cue' (in the sense of Grosz 2014) for the exclamation reading.

On the other hand, the question particles in (73), denn and wohl, signal that this T-to-C-movement configuration should be interpreted as a regular (i.e., informationseeking) $w h$-question. Given this situation, we can say that the interrogative reading of German wh-structures involving T-to-C-movement is always a combination of different linguistic means: T-to-C-movement, the use of certain question particles that can only be used in T-to-C-movement structures (like denn or wohl above), and non-exclamative question prosody.

In a way, T-to-C-movement and question particles add up to the A-EXC reading in German. This is why empirical work on German A-EXCs has shown that the question particles are virtually obligatory in the German version of How cool is that! (see Auer 2016 and our discussion in Sect. 3.2 above). In English, on the other hand, verb movement and subject inversion does the job of yielding the interrogative (the addressee-oriented) component of A-EXCs like How cool is that!, which the 
corresponding configurations without T-to-C movement (How cool that is!) lack. In other words, since English lacks T-to-C-movement in wh-exclamatives, there is no need in this language for extra cues signaling that How cool is that! is an A-EXC and not an exclamative (and thus a S-EXC). ${ }^{13}$

After having pointed out this important qualification, let us now return to the central claim in (69) above. According to (69), we can assume that the pragmatic difference in terms of illocutionary force between wh-exclamatives lacking $\mathrm{V}$-to-C movement and A-EXCs featuring $\mathrm{V}$-in- $\mathrm{C}$ is captured by the fact that only A-EXCs have a context index that contains the addressee-related value ' $A$ ' for ' $x$ '. In German, as we have pointed out above, further disambiguating devices may be used in order to signal that $\mathrm{V}$-in-C structures are indeed interpreted as interrogatives and thus do not pattern with verb-final exclamatives in lacking Deont $\mathrm{S}_{\mathrm{S}}$, Epist, and $\mathrm{A}$ altogether.

In sum, then, we can conclude that when speakers utter A-EXCs, the corresponding speech act can be paraphrased as in (74); on the degree component, see the semantics of $[w h+\mathrm{Adj}]$ in Sect. 2.2:

(74) ' $S$ wants from $A$ that it is common ground whether the degree to which $p$ holds goes beyond a threshold $\theta$.'

In other words, A-EXCs have a deontic-epistemic interpretation that wh-exclamatives lack and that they share with interrogatives. The derivation, according to this analysis and what we have claimed for the exclamation component in Sect. 2, can thus be represented as follows:

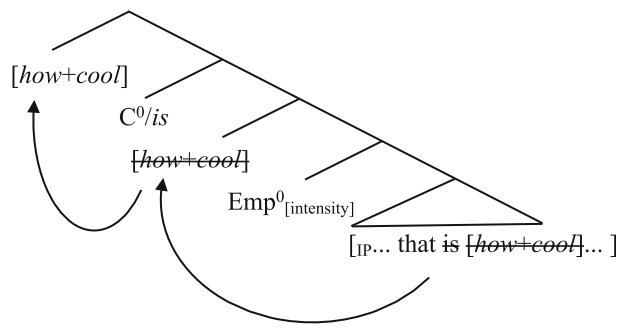

(75) spells out the claim that A-EXCs are in fact interrogatives with an additional exclamation component that can be analyzed along the lines of other cases where phrasal constituents receive a scalar reading by fronting them to the specifier of EmpP before they must move further for reasons of clausal typing. Note again that EmpP constitutes a syntactic layer that cannot be identified with the function of

\footnotetext{
13 Note that speaking of modal particles as 'cues' that signal a specific reading of a syntactic structure is compatible with formal (syntactic) approaches to modal particles in German (as, e.g., work by Grosz 2014 demonstrates). This terminology is thus not necessarily restricted to 'functional reasoning' as one of the reviewers has pointed out. Except for very special environments (e.g., so-called $o b$-verb-final interrogatives; see Sect. 3.2 above), modal particles in German are (syntactically) non-obligatory elements that 'signal' special readings of several sentence types (together with other 'cues' like intonation).
} 
clausal typing and/or illocutionary force. More specifically, Trotzke (2017a) has argued that emphasis in questions is a type of not-at-issue meaning whose operator must be below the Question operator for many empirical reasons (see Sect. 2 above).

The analysis for German A-EXCs (e.g., Wie geil ist das denn!) would look the same, except for the placing of the modal particle denn in the highest position of the middle field (IP zone); see Bayer and Obenauer (2011) and Bayer and Trotzke (2015) for extensive discussion and detailed derivations of modal particles in questions. The licensing of only a subset of question particles in A-EXCs can be explained by referring to both the illocutionary point of A-EXCs and the specific use conditions of these particles formulated in Sect. 3.2 above. In other words, the illocutionary meaning of A-EXCs in (76) is only compatible with particles that contribute the use condition in (77a), but it is incompatible with the use condition given in $(77 b)$ :

(76) ' $S$ wants from $A$ that it is common ground whether the degree to which $p$ holds goes beyond a threshold $\theta$.'

(77) a. use condition for denn, eigentlich, bitte:

'A believes that B is able to supply an answer to the question.'

b. use condition for wohl, nur, bloß, schon:

'that the obligation to answer the question is suspended.'

I follow Gutzmann (2015) and many others here in claiming that those incompatibilities should not be modeled in terms of syntactic mechanisms, but can be explained on purely pragmatic grounds (see also Grosz to appear for a general overview of this line of thought). Given this analysis of A-EXCs, let us now summarize the paper and also turn to the question again of how we should deal with all the remaining idiosyncratic properties of A-EXCs that we discussed in this paper.

\section{Conclusion}

In this paper, I focused on a subclass of non-standard uses of interrogatives, namely on special uses of how-interrogatives. After having discussed some general issues concerning the connection between sentence type and illocutionary form, I presented the new observation that utterances like English How cool is that! have in fact a hybrid status: they function as both speaker-oriented exclamations and addressee-oriented questions. Drawing on cross-Germanic evidence from English and German, I specified their pragmatic contribution as addressee-oriented exclamation and thus labeled these wh-configurations with interrogative form as $A-E X C s$. A-EXCs can be signaled by a dedicated class of modal particles in German, and their meaning difference to $w h$-exclamatives is clearly expressed by word order in both German and English. 
Taken together, the evidence discussed in this paper shows that these whconfigurations have a unique pragmatic function, and that this function is indicated by a combination of non-syntactic means and compositional syntax. As for syntactic work, I agree that A-EXCs are of course characterized by a complex interplay of intonational, syntactic, and lexical factors. A construction-oriented analysis that can assemble these diverse aspects under one 'construction' thus seems to be a natural account at first sight.

And indeed, a construction-based view of A-EXCs could, in principle, also account for the V-to-C-movement component of A-EXCs. Consider the following construction-based analysis of German V2-wh-questions by Jacobs (2016, 37), where 'FinP' is the Finiteness Phrase (and the propositional core of the clause), 'sub' stands for '-subordinated', 'prop' is the proposition, and 'ill-typ' the illocutionary type:

$$
\left(\begin{array}{lll}
\text { Phon: } & & \text { /XYZ/ } \\
\text { Syn: } & & {\left[X_{+\mathrm{W}}\left[Y_{\text {Fin }} Z_{\text {FinP,X,Y }}\right]\right]_{\text {-sub }}} \\
\text { Sem: } & \text { prop: } & \mathrm{W}_{\mathrm{X}}\left(\left(Y_{\mathrm{Fin}} Z_{\mathrm{Fin} P, \mathrm{X}, \mathrm{Y}}\right)^{\text {prop }}\right) \\
& \text { ill-typ: } & \text { FRAGE }(\text { prop })
\end{array}\right)
$$

According to a construction-based perspective, one could then argue that the characteristics of a general 'V-to-C-construction' (or here: a 'V-to-C-construction' involving a wh-element in SpecCP) could just be inherited by more specific constructions such as the 'A-EXC construction'. However, note that this would not be a case of 'strict inheritance' in the sense of Flickinger et al. (1985), where all properties of the general construction are inherited by the more specific construction.

More specifically, our discussion in the paper has shown that wh-questions and A-EXCs are still distinguished by, for instance, some intonational choices (e.g., heavy stress on the subject d-pronoun can in fact disambiguate between wh-question and A-EXC; see Sect. 3.1 above). Although one could then model these weaker relations between wh-question and A-EXC by using other formal tools (see, e.g., Sag's 2010 approach to English sentence types within Sign Based Construction Grammar and Boas and Ziem 2018 for a general constructionist approach to German syntax), my claim in this paper has merely been that, whatever formal model one would use, the connection between syntactic form and meaning in A-EXCs is by no means arbitrary and unrestricted. Since arbitrary form-function mappings are a cornerstone of a constructionist view on language, I argue that a compositional conception of sentence-type meanings can better explain what we observe in the case of minor sentence types such as How cool is that!

All in all, instead of giving up the idea of formulating a systematic relation between syntactic form and illocutionary potential (that also includes 'minor' types such as A-EXCs), I argued in this paper that such a compositional understanding of sentence meaning is relevant even for pragmatic uses that at first seem rather marginal and formally unrestricted. I hope to have shown that both systematic structural features and non-formal (sometimes also idiosyncratic) components are 
relevant for our understanding of syntactic constructions-also for the new ones that keep emerging continuously.

Acknowledgements I thank Lisa Brunetti, Agnès Celle, Hans-Martin Gärtner, Anastasia Giannakidou, Lucia M. Tovena, Xavier Villalba, and three anonymous reviewers for insightful comments and discussion. Special thanks are due to Jim Wood for his careful editorial work and to Sarah Felber, JCGL's copy editor. I gratefully acknowledge financial support from the German Academic Exchange Service/ DAAD (PPP project Surprise Questions from a Comparative Perspective; Grant No. 57444809) and from the Generalitat de Catalunya/Secretariat for Universities and Research of the Ministry of Economy and Knowledge (Grant No. 2017-BP00031).

Funding Open Access funding enabled and organized by Projekt DEAL.

Open Access This article is licensed under a Creative Commons Attribution 4.0 International License, which permits use, sharing, adaptation, distribution and reproduction in any medium or format, as long as you give appropriate credit to the original author(s) and the source, provide a link to the Creative Commons licence, and indicate if changes were made. The images or other third party material in this article are included in the article's Creative Commons licence, unless indicated otherwise in a credit line to the material. If material is not included in the article's Creative Commons licence and your intended use is not permitted by statutory regulation or exceeds the permitted use, you will need to obtain permission directly from the copyright holder. To view a copy of this licence, visit http:// creativecommons.org/licenses/by/4.0/.

\section{References}

Abraham, Werner. 1991. The grammaticization of the German modal particles. In Approaches to grammaticalization II, eds. Elizabeth Closs Traugott and Bernd Heine, 331-380. Amsterdam: John Benjamins.

Altmann, Hans. 1993. Satzmodus. In Syntax: Ein internationales Handbuch zeitgenössischer Forschung, ed. Joachim Jacobs, Arnim von Stechow, Wolfgang Sternefeld, and Theo Vennemann, 1006-1029. Berlin: Mouton de Gruyter.

Auer, Peter. 2016. "Wie geil ist das denn?" Eine Konstruktion im Netzwerk ihrer Nachbarn. Zeitschrift für germanistische Linguistik 44: 69-92.

Authier, J.-Marc, and Liliane Haegeman. 2019. The syntax of mirative focus fronting: Evidence from French. In Contributions of Romance languages to current linguistic theory, ed. Deborah L. Arteaga, 39-63. Cham: Springer.

Batliner, Anton. 1988. Der Exklamativ: Mehr als Aussage oder doch nur mehr oder weniger Aussage? Experimente zur Rolle von Höhe und Position des F0-Gipfels. In Intonationsforschungen, ed. Hans Altmann, 243-271. Tübingen: Niemeyer.

Bayer, Josef, and Hans-Georg Obenauer. 2011. Discourse particles, clause structure, and question types. The Linguistic Review 28: 449-491.

Bayer, Josef, and Andreas Trotzke. 2015. The derivation and interpretation of left peripheral discourse particles. In Discourse-oriented syntax, ed. Josef Bayer, Roland Hinterhölzl, and Andreas Trotzke, 13-40. Amsterdam: John Benjamins.

Beltrama, Andrea, and Andreas Trotzke. 2019. Conveying emphasis for intensity: Lexical and syntactic strategies. Language and Linguistics Compass 13: e12343.

Bianchi, Valentina, and Silvio Cruschina. 2016. The derivation and interpretation of polar questions with a fronted focus. Lingua 170: 47-68.

Boas, Hans C., and Alexander Ziem. 2018. Approaching German syntax from a constructionist perspective. In Constructional approaches to syntactic structures in German, ed. Hans C. Boas and Alexander Ziem, 1-46. Berlin: Mouton de Gruyter.

Brandner, Ellen. 2010. On the syntax of verb-initial exclamatives. Studia Linguistica 64: 81-115.

Braun, Bettina, Nicole Dehé, Jana Neitsch, Daniela Wochner, and Katharina Zahner. 2018. The prosody of rhetorical and information-seeking questions in German. Language and Speech. 
Cruschina, Silvio. 2012. Discourse-related features and functional projections. Oxford: Oxford University Press.

Cruschina, Silvio. 2019. Focus fronting in Spanish: Mirative implicature and information structure. Probus 31: 119-146.

d'Avis, Franz-Josef. 2016. Different languageas-Different sentence types? On exclamative sentences. Language and Linguistics Compass 10: 159-175.

Davies, Mark. 2013. The corpus of global web-based English (GloWbE). http://corpus.byu.edu/glowbe.

den Dikken, Marcel, and Anastasia Giannakidou. 2002. From hell to polarity: 'Aggressively non-dlinked' wh-phrases as polarity items. Linguistic Inquiry 33: 31-61.

Destruel, Emilie, David I. Beaver, and Elizabeth Coppock. 2019. It's not what you expected! The surprising nature of cleft alternatives in French and English. Frontiers in Psychology 10: 1400. https://doi.org/10.3389/fpsyg.2019.01400.

Dörre, Laura, and Andreas Trotzke. 2019. The processing of secondary meaning: An experimental comparison of focus and modal particles in wh-questions. In Secondary content: The semantics and pragmatics of side issues, ed. Daniel Gutzmann and Katharina Turgay, 143-167. Leiden: Brill.

Eckardt, Regine. 2009. The real, the apparent, and what is eigentlich. Oslo Studies in Language 1: 77108.

Elliott, Dale E. 1974. Toward a grammar of exclamations. Foundations of Language 11: 231-246.

Finkbeiner, Rita. 2015. "Wie deutsch ist DAS denn?!” Satztyp oder Konstruktion? In Sendbote zwischen den Kulturen. Gustav KorlÕn und die germanistische Tradition an der Universitðt Stockholm, eds. Charlotta Seiler Brylla and Elisabeth Wåghäll Nivre, 243-273. Stockholm: Acta Universitatis Stockholmiensis.

Finkbeiner, Rita. 2018. Warum After Work Clubs in Berlin nicht funktionieren: Zur Lizensierung von w-Überschriften in deutschen Pressetexten. Linguistische Berichte/Sonderhefte 25: 21-46.

Flickinger, Daniel, Carl Pollard, and Thomas Wasow. 1985. Structure-sharing in lexical representation. Proceedings of the Twenty-third Meeting of the Annual Association of Computational Linguistics (ACL 23): 262-267.

Fried, Mirjam. 2015. Construction Grammar. In Syntax: Theory and analysis, vol. 2, ed. Tibor Kiss and Artemis Alexiadou, 974-1003. Berlin: Mouton de Gruyter.

Ginzburg, Jonathan, and Ivan A. Sag. 2000. Interrogative investigations: The form, meaning, and use of English interrogatives. Stanford, CA: CSLI Publications.

Grimshaw, Jane. 1979. Complement selection and the lexicon. Linguistic Inquiry 10: 279-326.

Grosz, Patrick G. 2012. On the grammar of optative constructions. Amsterdam: John Benjamins.

Grosz, Patrick. 2014. Optative markers as communicative cues. Natural Language Semantics 22: 89-115.

Grosz, Patrick. to appear. Discourse particles. In The Companion to Semantics, eds. Lisa Matthewson, Cécile Meier, Hotze Rullmann, and Thomas E. Zimmermann. Oxford: Wiley.

Gutzmann, Daniel. 2015. Use-conditional meaning: Studies in multidimensional semantics. Oxford: Oxford University Press.

Gyuris, Beáta, and Katalin Mády. 2013. Approaching the prosody of Hungarian wh-exclamatives. In VLLXX: Papers presented to LÃszloe Varga on his 70th birthday, ed. Péter Szigetvári, 333-349. Budapest: ELTE.

Jacobs, Joachim. 2016. Satztypkonstruktionen und Satztypsensitivität. In Satztypen und Konstruktionen, ed. Rita Finkbeiner and Jörg Meibauer, 23-71. Berlin: Mouton de Gruyter.

Jamieson, Elyse Anne. 2018. Questions, biases and 'negation': Evidence from Scots varieties. PhD dissertation, University of Edinburgh.

Kennedy, Christopher, and Louise McNally. 2005. Scale structure, degree modification, and the semantics of gradable predicates. Language 81: 345-381.

König, Ekkehard. 1977. Modalpartikeln in Fragesätzen. In Aspekte der Modalpartikeln, ed. Harald Weydt, 115-130. Tübingen: Niemeyer.

König, Ekkehard, and Peter Siemund. 2007. Speech act distinctions in grammar. In Language typology and syntactic description, ed. Timothy Shopen, 276-324. Cambridge: Cambridge University Press.

König, Ekkehard, and Peter Siemund. 2013. Satztyp und Typologie. In Satztypen des Deutschen, ed. Jörg Meibauer, Markus Steinbach, and Hans Altmann, 846-873. Berlin: Mouton de Gruyter.

Krifka, Manfred. 2011. Questions. In Semantics: An International Handbook of Natural Language Meaning, vol. 2, ed. Klaus von Heusinger, Claudia Maienborn, and Paul Portner, 1742-1785. Berlin: Mouton de Gruyter.

Lasnik, Howard, and Mamuro Saito. 1984. On the nature of proper government. Linguistic Inquiry 15: 235-289. 
Meibauer, Jörg. 1994. Modaler Kontrast und konzeptuelle Verschiebung: Studien zur Syntax und Semantik deutscher Modalpartikeln. Tübingen: Niemeyer.

Munaro, Nicola, and Hans-Georg Obenauer. 1999. On underspecified wh-elements in pseudointerrogatives. University of Venice Working Papers in Linguistics 9: 181-253.

Nye, Rachel. 2009. How pseudo-questions and the interpretation of wh-clauses in English. MA thesis, University of Essex.

Obenauer, Hans-Georg. 2006. Special interrogatives: Left periphery, wh-doubling, and (apparently) optional elements. In Romance Languages and Linguistic Theory 2004, ed. Jenny Doetjes and Paz González, 247-273. Amsterdam: John Benjamins.

Pesetsky, David. 1987. Wh-in situ: Movement and unselective binding. In The representation of (in) definiteness, ed. Eric J. Reuland and Alice G. Ter Meulen, 98-129. Cambridge, MA: MIT Press.

Reis, Marga. 1999. On sentence types in German: An enquiry into the relationship between grammar and pragmatics. Interdisciplinary Journal for Germanic Linguistics and Semiotic Analysis 4: 195-236.

Repp, Sophie. 2013. D-linking vs. degrees: Inflected and uninflected 'welch' in exclamatives and rhetorical questions. In Interfaces of morphology, ed. Holden Härtl, 59-90. Berlin: Akademie Verlag.

Repp, Sophie. 2015. On the acoustics of $w h$-exclamatives and $w h$-interrogatives: Effects of information structure and sex of speaker. In Proceedings of the 18th International Congress of Phonetic Sciences, ed. The Scottish Consortium for ICPhS 2015, Article 319, 1-5. Glasgow, UK: The University of Glasgow.

Rett, Jessica. 2011. Exclamatives, degrees and speech acts. Linguistics and Philosophy 34: 411-442.

Rizzi, Luigi. 2014. Syntactic cartography and the syntacticisation of scope-discourse semantics. In Mind, values, and metaphysics, ed. Anne Reboul, 517-533. Dordrecht: Springer.

Sag, Ivan A. 2010. English filler-gap constructions. Language 86: 486-545.

Siemund, Peter. 2015. Exclamative clauses in English and their relevance for theories of clause types. Studies in Language 39: 697-727.

Taniguchi, Ai. 2017. The formal pragmatics of non-at-issue intensification in English and Japanese. $\mathrm{PhD}$ dissertation, Michigan State University.

Tenny, Carol L. 2006. Evidentiality, experiencers, and the syntax of sentience in Japanese. Journal of East Asian Languages 15: 245-288.

Theiler, Nadine. 2018. The precondition particle: A unified analysis of German denn. Proceedings of NELS 48: 131-144.

Thurmair, Maria. 1989. Modalpartikeln und ihre Kombinationen. Tübingen: Niemeyer.

Thurmair, Maria. 2013. Satztyp und Modalpatikeln. In Satztypen des Deutschen, ed. Jörg Meibauer, Markus Steinbach, and Hans Altmann, 627-651. Berlin: Mouton de Gruyter.

Trotzke, Andreas. 2017a. The grammar of emphasis: From information structure to the expressive dimension. Berlin: Mouton de Gruyter.

Trotzke, Andreas. 2017b. Mirative fronting in German: Experimental evidence. Review of Cognitive Linguistics 15: 460-488.

Trotzke, Andreas. 2019. Approaching the pragmatics of exclamations experimentally. Proceedings of the Chicago Linguistic Society 54: 527-540.

Trotzke, Andreas, and Liliane Haegeman. in press. PP-internal particles in Dutch as evidence for PPinternal discourse structure. In Particles in German, English and beyond, eds. Remus Gergel, Ingo Reich, and Augustin Speyer. Amsterdam: John Benjamins.

Trotzke, Andreas, and Giuseppina Turco. 2015. The grammatical reflexes of emphasis: Evidence from German wh-questions. Lingua 168: 37-56.

Truckenbrodt, Hubert. 2006. On the semantic motivation of syntactic verb movement to C in German. Theoretical Linguistics 32: 257-306.

Truckenbrodt, Hubert. 2013. Selbständige Verb-Letzt-Sätze. In Satztypen des Deutschen, ed. Jörg Meibauer, Markus Steinbach, and Hans Altmann, 232-246. Berlin: Mouton de Gruyter.

van Bergen, Geertje, Rik van Gijn, Lotte Hogeweg, and Sander Lestrade. 2011. Discourse marking and the subtle art of mind-reading: The case of Dutch eigenlijk. Journal of Pragmatics 43: 3877-3892.

Villalba, Xavier. 2017. Non-asserted material in Spanish degree exclamatives: An experimental study on extreme degree. In Advances in the analysis of Spanish exclamatives, ed. Ignacio Bosque, 139-158. Columbus, OH: Ohio State University Press.

Wegener, Heide. 2002. The evolution of the German modal particle 'denn'. In New reflections on grammaticalization, ed. Ilse Wischer and Gabriele Diewald, 379-393. Amsterdam: John Benjamins. 
Zanuttini, Raffaella, and Paul Portner. 2003. Exclamative clauses: At the syntax-semantics interface. Language 79: 39-81.

Zimmermann, Malte. 2009. Asymmetry markers in discourse: The expressive meaning of bitte 'please'. In Proceedings of the 10th Symposium on Logic and Language, ed. László Kálmán, 53-61. Budapest: Research Institute for Linguistics, Hungarian Academy of Sciences (HAS), and Theoretical Linguistics Program, Eötvös Loránd University (ELTE).

Zobel, Sarah, and Eva Csipak. 2017. Conditional antecedents containing the German discourse particle 'denn': A corpus study. Linguistica 56: 345-361.

Publisher's Note Springer Nature remains neutral with regard to jurisdictional claims in published maps and institutional affiliations. 